\title{
Identification of neomales in South American catfish Rhamdia quelen on the basis of the sex ratio in the progeny
}

\author{
Luciano Augusto Weiss ${ }^{1}$, Jurandir Joaquim Bernardes Júnior, Alex Pires de Oliveira Nuñer \\ Laboratory of Biology and Freshwater Fish Farming, Aquaculture Department, Agricultural Sciences Center, Federal University \\ of Santa Catarina. Florianópolis, SC, Brazil.
}

\begin{abstract}
In the present study, we aimed to identify masculinized genotypic females of Rhamdia quelen on the basis of the sex ratio of the progeny. Masculinizing diets containing 3 levels of $17 \alpha$-methyltestosterone (MT; 60,90 , or $120 \mathrm{mg} \mathrm{kg}^{-1}$ ) were administered to $R$. quelen fry. Thereafter, 5 phenotypic males from each MT treatment were crossed with normal females, and their progenies were sexed. At least 1 male from each treatment group generated progeny with a higher female:male ratio. These males, designated M60, M90, and M120, were crossed again with 3 other normal females to re-evaluate the sex ratio of the progeny. Moreover, a normal male was used as a control. Again, we found a higher female:male ratio in the progeny of M60, M90, and M120. The control male produced 2 sets of balanced progeny and 1 with a lower female:male ratio. Although these breeders did not generate all-female progeny $(79.75 \pm 7.20 \%$ of females), our findings indicate that M60, M90, and M120 can be considered masculinized genotypic females of $R$. quelen, suggesting the involvement of autosomal genes or polygenic interactions in sex determination.
\end{abstract}

Keywords: $17 \alpha$-methyltestosterone, indirect sex reversal, silver catfish.

\section{Introduction}

Monosex is a highly desired condition for many fish culture systems, primarily owing to differences in growth performance between males and females or unwanted reproduction during the production cycle (Dunham, 2004). Sex reversal is an important alternative approach available to prevent heterogeneous growth in fish farming, which can be induced by temperature (Baroiller et al., 1999) or hormone administration via dietary supplementation, immersion bath, injection, or implants (Pandian, 2013).

The South American catfish Rhamdia quelen (Siluriformes, Heptapteridae) is a gonochoristic species with a broad distribution in the Neotropics, and it is well adapted to aquaculture conditions (Barcellos et al., 2001). In recent years, commercial production of this fish has significantly increased in southern Brazil (Silveira et al., 2014). Owing to a higher rate of growth in females and the early maturation of males during the production cycle (Gomes et al., 2000; Fracalossi et al., 2002; Ghiraldelli et al., 2007), monosex female cultures have the potential to increase the production volume of this species.

Although sex reversal is generally induced directly in fish by administering steroids during the initial phases of development (Pandian, 2013), the use of synthetic steroids in farmed fish has sparked controversy regarding the potentially detrimental effects on human health and the environment. Moreover, it can negatively affect healthy fish development. For these reasons, this practice is prohibited in many European countries (Desprez et al., 2003; El-Sayed, 2006).

Without the use of exogenous hormones, female progeny might be obtained by crossing masculinized genotypic females that are phenotypically male (neomale breeders) with normal females (i.e., both phenotypically and genotypically females). This indirect method of sex reversal has been applied to commercial salmonid farming (Hunter et al., 1983; Piferrer and Donaldson, 1989; Feist et al., 1995), and it helps to avoid the use of hormones in fish raised for human consumption. Indirect sex reversal initially involves masculinizing genotypic females with an androgenic hormone to obtain neomale breeders and later fertilizing the oocytes from normal females with semen from neomales, which should theoretically produce offspring composed purely of normal females, depending on the sex determination system. These female offspring would be free of exogenous hormones.

In $R$. quelen from the Iguaçu River, Fenocchio et al. (2003), related that there are no differences in chromosomes between sexes. However, the existence of sex chromosomes in $R$. quelen, or the type of sex determination system is not known, to the best of our knowledge. In classical sex determination systems, females that are homogametic for the sex chromosome $(\mathrm{XX} / \mathrm{XY})$ model would theoretically produce all female progeny when crossed with neomales (XX; Kavumpurath and Pandian, 1994; Gomelsky, 2003). Likewise, for species in which the females are heterogametic (ZW/ZZ model), all female progeny would be generated by crossing a normal male (ZZ) with superfemales (WW), which would originate from neomales (ZW; genetically female and phenotypically male; Toledo-Filho et al., 1996). However, for some species, sex chromosomes and autosomal genes determine the sex, and the latter are influenced by genetic and environmental factors. This sex-determining mechanism would limit the development of all-female progeny using neomales or superfemale breeders (Devlin and Nagahama, 2002; Kirankumar and Pandian, 2002; Desprez et al., 2006).

The survival of fish subjected to sex reversal and 
those carrying the desired genotype until sexual maturation is typically very low (George and Pandian, 1996; Pandian, 2013). The sex reversal process thus demands a considerable investment of time and resources to produce a broodstock of sex-reversed individuals. Therefore, the total number of fish produced limits the use of lethal methods to determine the efficacy of the sex reversal process. However, progeny tests aimed at comparing the sex ratios of progeny from different parent fish allows the evaluation of sexual composition of the progeny of sex-reversed fishes and enables the formation of a broodstock of such breeders. Therefore, the present study aimed to identify masculinized genotypic female breeders of $R$. quelen using progeny tests based on the sex ratio.

\section{Materials and Methods}

The study was conducted at the Laboratory of Biology and Freshwater Fish Farming, (LAPAD; $27^{\circ} 43^{\prime} 44.4^{\prime \prime} \mathrm{S}, 48^{\circ} 30^{\prime} 32.8^{\prime \prime} \mathrm{W}$ ) at the Federal University of Santa Catarina, Aquaculture Department, using experimental procedures approved by the Animal Ethics Committee (Protocol PP00788 - Development of Technology for the Farming of Native Fish).

The study was conducted in 3 steps: I) masculinization of the larvae over 21 days and growth of the masculinized fish for 240 days until the attainment of sexual maturation; II) first progeny test with a duration of 150 days to find breeders from the masculinization with a higher frequency of females in their progenies; III) the second progeny test started 30 days after the end of the first test, also over 150 days, to confirm the sexual proportion of the progenies generated by the masculinized females.

\section{Biological material}

$R$. quelen larvae used in the masculinizing treatments were obtained through the artificial reproduction of wild specimens captured in the upstream portion of the Uruguay River $\left(27^{\circ} 31^{\prime} 32.0^{\prime \prime} \mathrm{S}\right.$, $\left.51^{\circ} 47^{\prime} 21.2^{\prime \prime} \mathrm{W}\right)$ and were maintained in the LAPAD breeder bank. One specimen was deposited in the Museum of Zoology of the State University of Londrina, Paraná, Brazil (MZUEL 10549). Reproduction was induced by hypophysation (Woynarovich and Horváth, 1983), wherein pool from 2 females and 1 semen pool from 2 males were used. The fertilized eggs were incubated (cylinder-conical incubator) using a controlled water recirculation system at a temperature of $25.2 \pm 0.2^{\circ} \mathrm{C}$

\section{Masculinization}

17 $\alpha$-methyltestosterone (MT; Sigma, St Louis, MO, USA) was incorporated into a commercial diet (Guabi ${ }^{\circledR}$ Pirá alevinos 55, Campinas, São Paulo, Brazil) at doses of 60,90 , or $120 \mathrm{mg} \mathrm{kg}^{-1}$ of feed according to the ethyl alcohol evaporation method (Shelton et al., 1981). All diets were sieved (using mesh sizes of 0-250, 250-650, and 650-850 $\mu \mathrm{m}$ ), individually packed, and refrigerated until the first (mesh of $0-250 \mu \mathrm{m}$ ), second (mesh of 250-650 $\mu \mathrm{m}$ ), and third (mesh of 650-850 $\mu \mathrm{m}$ ) weeks of feeding. Larvae at the onset of exogenous feeding, i.e., 2 days after hatching (DAH), were split into 3 groups ( 1 group per dosage), and each group was administered a different dose of MT 5 times a day for 21 days. After the masculinizing treatment period, the fish were in a controlled water recirculation system at an average temperature of $25.3 \pm 1.4^{\circ} \mathrm{C}$ and under a $12 \mathrm{~h}$ light-dark cycle until sexual maturation. Eight-monthold phenotypic males from each dosage group were stimulated to release semen by applying light pressure to the abdomen and were individually marked with passive integrated transponder tags (Mini Transponder Trovan $^{\circledR}$, Santa Barbara, CA, USA) for identification purposes during the progeny tests.

\section{Progeny tests}

Two progeny tests were conducted to identify neomales. In the first test, semen from each male coming from masculinization treatments was used to fertilize a pool of oocytes from 2 wild females, and the males that produced progeny with a prevalence of females $(P<0.05)$ were selected. In the second test, the males selected from the first test were used to fertilize separate aliquots of oocytes manually collected from 3 wild females (different from those used during the first test) to confirm the prevalence of females in the progeny.

\section{Test I}

In this test, we used 5 phenotypic males from each MT dose group $\left(60,90\right.$, and $120 \mathrm{mg} \mathrm{kg}^{-1}$ of feed) with mean weights \pm SD of $156.54 \pm 46.11 \mathrm{~g}, 316.20 \pm$ $98.67 \mathrm{~g}$, and $277.18 \pm 59.08 \mathrm{~g}$, respectively, and 2 females from the broodstock of wild breeders with a mean weight of $650.20 \pm 212.06 \mathrm{~g}$. The selected females had a swollen abdomen and reddish genital papilla, which are typical characteristics of females suitable for artificial reproduction. Spawning was induced in all fish through hypophysation (Woynarovich and Horváth, 1983). The females received 2 doses $(0.5$ and $5.0 \mathrm{mg} \mathrm{kg}$ ${ }^{1}$ ) of carp pituitary extract (CPE; Danúbio Aquacultura, Blumenau, Santa Catarina, Brazil) with a $12 \mathrm{~h}$ interval between doses, and the males received 1 dose $(4.0 \mathrm{mg}$ $\mathrm{kg}^{-1}$ ) at the time the second dose was applied to the females. After manual collection and pooling of the oocytes from the females, $5 \mathrm{~g}$ aliquots were individually fertilized with each collected semen sample. The fertilized eggs were separately incubated in a conicalcylinder incubator connected to a controlled water recirculation system at $24.9 \pm 0.4^{\circ} \mathrm{C}$.

The progeny of each male was reared separately for 150 days in circular tanks $(60 \mathrm{~L})$ using a controlled water recirculation system with an initial density of 6 larvae per liter of water. These fry were fed exclusively with newly hatched nauplii of Artemia sp. for 15 days (Inve Aquaculture Inc., Salt Lake City, UT, USA) that had previously been maintained for $30 \mathrm{~min}$ in an immersion bath containing an enriched solution $(1 \mathrm{~L}$ distilled water, $12 \mathrm{~g}$ bovine liver powder, $9 \mathrm{~g}$ casein, $2 \mathrm{~g}$ choline chloride, $10 \mathrm{~g}$ vitamin and mineral PREMIX, 40 
$\mathrm{ml}$ crude fish oil, and $60 \mathrm{ml}$ sunflower oil) to improve larval nutrition. The ingredients and amounts of the enriched solution were adapted from Cardoso et al. (2004) and Dias et al. (2011). Between days 15 and 30, the larvae were fed enriched Artemia simultaneously with a sieved mixture $(1: 1 ; 650-850 \mu \mathrm{m})$ of bovine liver powder and commercial flocculated micro-feed (Alcon ${ }^{\circledR}$ Alevinos, Camboriú, Santa Catarina, Brazil). After 30 days, the Artemia were removed from the feed, and only the mixture of bovine liver powder and commercial flocculated micro-feed was provided until the juveniles reached 2 months of age, when they began to receive commercial extruded feed (Guabi Pirá 40 ${ }^{\circledR}$, Guabi Nutrição e Saúde Animal SA, Campinas, São Paulo, Brazil).

At $150 \mathrm{DAH}, 30$ fish from each progeny group were randomly sampled and euthanized by submersion in $100 \mathrm{mg} \mathrm{L}^{-1}$ eugenol (Iodontosul ${ }^{\circledR}$ Eugenol, Porto
Alegre, Rio Grande do Sul, Brazil) for 5 min prior to the removal of the gonads for sex determination. For the groups that exhibited a significant deviation from a 1:1 sex ratio in favor of females $(\mathrm{P}<0.05)$, the sampling was extended to 90 fish or to all fish in the experimental unit when the number of fish was less than 90 .

The gonads were removed by ventral incision, and sex was macroscopically determined (Fig. 1a, 1b). For fish with small gonads that could not be sexed macroscopically, sex was determined using an imprint of gonadal tissue on glass slides (without the use of dyes), which was observed under a light microscope (LED Leica ${ }^{\circledR}$ DM 3000, Bannockburn, IL, USA; Fig. 1c, 1d). The fish with undifferentiated gonads were excluded, i.e., only the fish with gonads that could be sexed were considered in the evaluation of the sex ratio. At the time of sexing, individual biometrics, including fish weight $(\mathrm{g})$ and total length (cm), were determined. a)

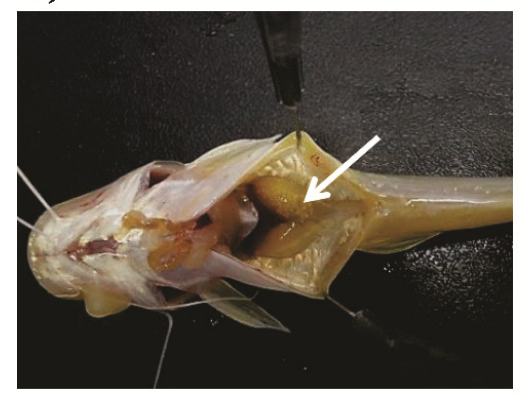

c)

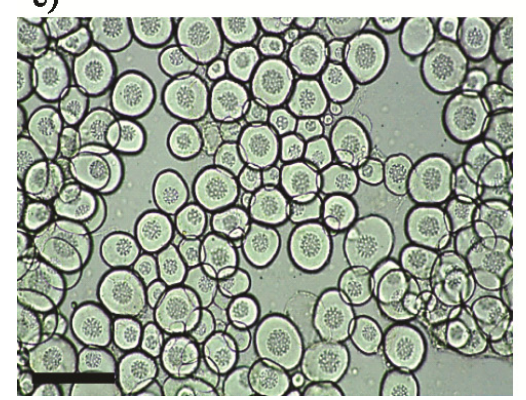

Test II

The phenotypic males from test I that generated the highest percentage of female progeny were used in test II, 6 months after the initiation of the first test. Semen from each male was used to fertilize separate 3 mature wild females, with a weight of 733.49 $\pm 94.48 \mathrm{~g}$, derived from a broodstock of breeders (different from those used in the first test). During this progeny test II, the semen of 1 male from the broodstock of wild breeders (weight of $310.0 \mathrm{~g}$ ) that did not receive a masculinizing treatment was used as a control. Reproduction was induced in all fish. The progeny were reared and sexed following the protocols used in the first test. However, in test II, all fish present in the experimental units were sampled; the minimum number of fish analyzed was 50 .

\section{Statistical analyses}

The male to female ratio was evaluated using
Figure 1. View of the gonads used for sexing the progeny of Rhamdia quelen generated from crosses between normal females and neomales. a) Female gonads with paired saculiform structures of a translucent yellowish color. b) Male gonads with paired elongated whitish structures. c) Apparent oocytes produced using the imprint of gonadal tissue on a glass slide. d) Digitiform projections of the male gonads produced from the imprint of gonadal tissue on a glass slide. Bars: $200 \mu \mathrm{m}$. the chi-square test and an expected sex ratio of 1:1 (Zar, 2010).

In the first progeny test, the male to female ratios of all progeny groups were subjected to the chisquare heterogeneity test $(\alpha=0.05)$ to test the hypothesis $\left(\mathrm{H}_{0}\right)$ that the male to female ratio was independent of the male breeder (Zar, 2010). The test was applied again because of the presence of heterogeneity, and 2 progeny groups were compared: I) groups with a higher male:female ratio or a balanced (1:1) ratio and II) groups with a higher female:male ratio.

In the second progeny test, the progeny of each male breeder was subjected to the heterogeneity test to test the hypothesis that the sex ratios between the progeny groups were similar regardless of the breeding females.

\section{Results}

Of the fish sexed during the progeny tests, $8 \%$ exhibited undifferentiated gonads. Crosses between normal females and neomales produced progeny with 
$79.75 \pm 7.20 \%$ females

Test I

The mean weight and total length \pm SD of all generated progeny were $6.56 \pm 4.17 \mathrm{~g}$ and $9.89 \pm 1.81$ $\mathrm{cm}$, respectively. One phenotypic male from each MT dosage group produced progeny with a higher female:male ratio $(\mathrm{P}<0.05)$, whereas the sex ratio was $1: 1(\mathrm{P}>0.05)$, or the percentage of males was higher $(\mathrm{P}<0.05)$ in the other progeny groups (Table 1$)$. Only 1 male (from the $60 \mathrm{mg} \mathrm{kg}^{-1}$ feed MT treatment) did not respond to induction with $\mathrm{CPE}$ and did not release semen for fertilization.

The heterogeneity test indicated that the effect of the male breeder on the sex ratio of the progeny was significant $\left(\chi^{2}=68.92 ; d f=13 ; \mathrm{P}<0.05\right)$. When the progenies were combined, as described in section 2.3.3, and the sex ratios compared, no effect of the male breeder was observed between the pooled group consisting of the progeny groups with a $1: 1$ sex ratio or a higher male:female ratio $\left(\chi^{2}=9.62 ; d f=10 ; \mathrm{P}=0.47\right)$ and the pooled group consisting of progeny groups with a higher female:male ratio $\left(\chi^{2}=3.25 ; d f=2 ; \mathrm{P}=0.20\right)$.
Therefore, the heterogeneity resulting from the combination of all progeny can be attributed to the prevalence of females in the progeny generated by 3 males, 1 from each masculinizing dose, which were designated M60, M90, and M120.

Test II

The mean weight and total length \pm SD of all generated progeny were $10.14 \pm 3.46 \mathrm{~g}$ and $10.74 \pm 1.29$ $\mathrm{cm}$, respectively. The percentage of females was significantly higher $(\mathrm{P}<0.05)$ in the progeny from each of the phenotypic males in all masculinization treatments (M60, M90, and M120), corroborating the results obtained in the first progeny test (Fig. 2). The prevalence of females obtained in the heterogeneity test was consistent with the progeny obtained from each male regardless of the breeding female, demonstrating that these specimens of $R$. quelen are masculinized genotypic females (neomale breeders). In the crosses between the control male and breeding wild females, 2 progenies exhibited a 1:1 sex ratio, and 1 had a higher male:female ratio, resulting in sex ratio heterogeneity $\left(\chi^{2}=9.99 ; d f=2 ; \mathrm{P}<0.05\right)$.

Table 1. Numbers of male and female progeny from progeny test I in which normal Rhamdia quelen females of a wild-breeding broodstock (the pool from 2 females) were crossed with phenotypic males produced in masculinizing treatments using $17 \alpha$-methyltestosterone $(\mathrm{MT}) .{ }^{*}$ Significantly different sex ratio using the chi-square test $(\mathrm{P}<0.05)$, considering an expected ratio of 1:1. -- Specimen that did not respond to hormonal induction with CPE to release semen.

\begin{tabular}{|c|c|c|c|c|c|c|}
\hline \multirow{3}{*}{ Breeding males } & \multicolumn{6}{|c|}{ MT kg of feed $^{-1}$} \\
\hline & \multicolumn{2}{|c|}{$60 \mathrm{mg} \mathrm{kg}^{-1}$} & \multicolumn{2}{|c|}{$90 \mathrm{mg} \mathrm{kg}^{-1}$} & \multicolumn{2}{|c|}{$120 \mathrm{mg} \mathrm{kg}^{-1}$} \\
\hline & $\hat{o}(\%)$ & $q(\%)$ & $\hat{\sigma}(\%)$ & $q(\%)$ & $\hat{0}(\%)$ & $q(\%)$ \\
\hline 1 & $16(53)$ & $14(47)$ & $18(60)$ & $12(40)$ & $13(43)$ & $17(57)$ \\
\hline 2 & $23 *(77)$ & $07(23)$ & $18(60)$ & $12(40)$ & $18(60)$ & $12(40)$ \\
\hline 3 & $22(24)$ & $68 *(76)$ & $18(60)$ & $12(40)$ & $12(13)$ & $78 *(87)$ \\
\hline 4 & $21 *(70)$ & $09(30)$ & $24 *(80)$ & $06(20)$ & $23 *(77)$ & $07(23)$ \\
\hline 5 & -- & -- & $24(27)$ & $64 *(73)$ & $12(48)$ & $13(52)$ \\
\hline
\end{tabular}

Female 1
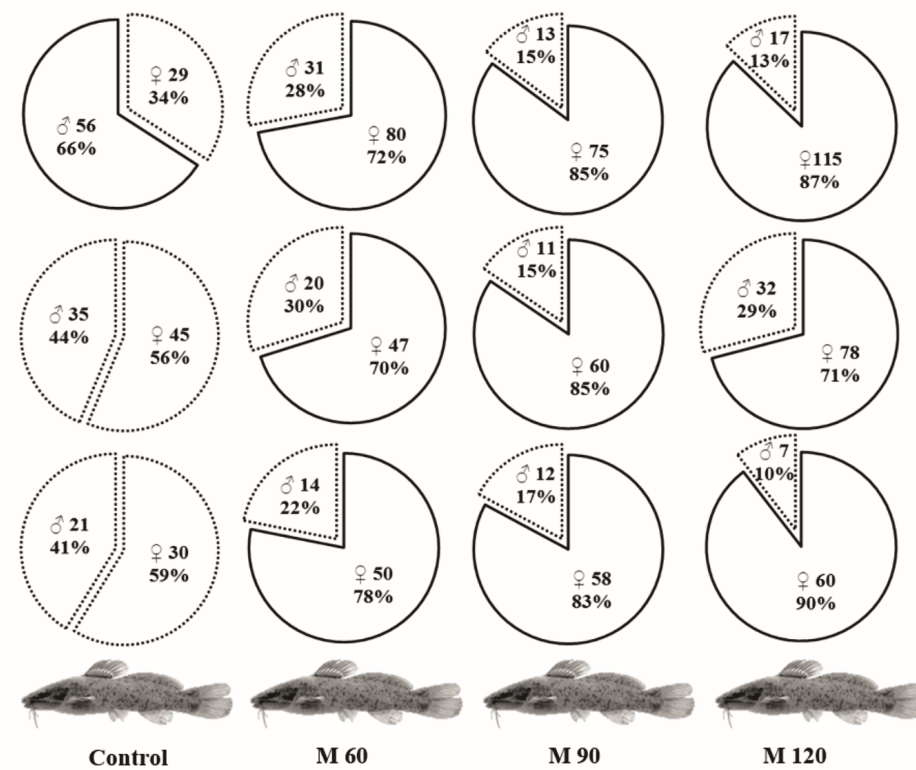

Control

M 6
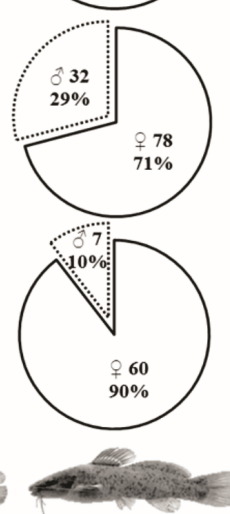

M 120
Figure 2. Sex ratio of the progeny of Rhamdia quelen generated in progeny test II of normal females with individuals masculinized with 1 of 3 doses of $17 \alpha$ methyltestosterone-60 (M60), 90 (M90), or 120 (M120) $\mathrm{mg} \mathrm{kg}^{-1}$ of feed-and a control male. In all the 3 treatments, solid lines indicate a higher presence of females, and dotted lines indicate a lower presence of males. In the controls, solid lines represent a higher presence of males, and dotted lines represent a balanced (1:1) sex ratio using the chi-square test $(\mathrm{P}<0.05)$, considering an expected sex ratio of $1: 1$. 


\section{Discussion}

The phenotypic males produced in the different treatment groups and evaluated in the progeny tests were maintained in a water recirculation system at 25.3 $\pm 1.4^{\circ} \mathrm{C}$ and under a $12 \mathrm{~h}$ light-dark cycle from the initial phases of life. Under these conditions, they matured at the age of 8 months, which is similar to the age at maturity observed in $R$. quelen in soil fish ponds in southern Brazil (Ghiraldelli et al., 2007). In contrast, neofemales (feminized males) of Betta splendens show delayed sexual maturation compared with normal females (Pandian et al., 1994). However, the testicular development of $R$. quelen neomales mirrors that of normal males, which was demonstrated by both types of males releasing semen at the same age. Apparently, the formation of the sperm duct in $R$. quelen neomales occurs without abnormalities (another important characteristic of $R$. quelen neomales breeders), in contrast to that observed in Oncorhynchus mykiss, in which neomales do not have sperm ducts and need to be euthanized to collect semen (Kowalski et al., 2011).

Only $8 \%$ of all fish sexed during the progeny tests exhibited undifferentiated gonads, indicating that at 150 days old, the gonads of most fish could be identified macroscopically or microscopically by using the imprint of gonadal tissue on glass slides. In Oreochromis niloticus, sexing can be performed after the age of 90 days, regardless of the method used: macroscopic examination of the urogenital papilla, microscopic examination of gonads freshly stained with acetate-carmine, or histological analysis of the gonads (Makino et al., 2009).

A 1:1 sex ratio or a higher male:female ratio in the progeny generated in test I by males was consistent with those obtained from crosses with the untreated wild male (male control) in the second progeny test, demonstrating that the crosses occurred with phenotypic and genotypic males. In contrast, the prevalence of females among the progeny of the phenotypic males from the treatment groups M60, M90, and M120 in both progeny tests demonstrates that these animals can be considered neomale breeders. Although a full female progeny was not produced, each of these neomales participated in 4 crosses, and the prevalence of females was significant in the progeny regardless of the wild female breeder used.

Entirely female progeny is expected in a cross between a normal homogametic female (XX) and a neomale $(\mathrm{XX})$, as is observed in salmonids (Donaldson and Devlin, 1996). This outcome does not occur in some species owing to the influence of other genetic and environmental factors (particularly temperature) on sex determination, in addition to the influence of sex chromosomes (Devlin and Nagahama, 2002; Kirankumar and Pandian, 2002; Desprez et al., 2006). Progeny tests with XX neomales of Betta splendens produced $13 \%$ males in the progeny, indicating the possible participation of autosomal genes in sex determination (Kirankumar and Pandian, 2002). In Perca fluviatilis, crosses between normal females and neomales result in progeny comprising 95-100\% females, whereas normal males of this species generate an unbalanced sex ratio that could be in favor of either sex (Rougeot et al., 2002). The authors of the study suggest that a model with homogametic females (XX) is affected by autosomal or polygenic factors in sex determination.

Water temperature is one of the main factors that can affect physiological sexual differentiation in fish (Nakamura et al., 1998; Ospina-Álvarez and Piferrer, 2008). However, different temperatures (19, 25 and $30^{\circ} \mathrm{C}$ ) at the time of egg fertilization and incubation (Longo and Nuñer, 2010) or during the early developmental stage $\left(19,24\right.$, and $29^{\circ} \mathrm{C}$; Sulis-Costa et al., 2013) did not alter the sex ratio of $R$. quelen.

Because sex determination involves complex pathways, the participation of autosomal genes is expected in cases in which the sex ratio of the progeny is unbalanced (Devlin and Nagahama, 2002). Considering that the presence of sex chromosomes has not been observed for $R$. quelen and that the sex determination system of this species has not been fully elucidated, sex determination might depend on a set of autosomal chromosomes, as occurs in Pseudoplatystoma corruscans, another Siluriformes species (Piferrer, 2001). However, belonging to the same order or genus does not necessarily imply similarities in the mechanisms involved in sex determination. The genus Oreochromis has 2 sex determination models: homogametic males (ZZ/ZW) and homogametic females (XX/XY) (Mair et al., 1991; Müller-Belecke and Hörstgen-Schwark, 1995). However, deviations in the sex ratios of the progeny suggest the involvement of other factors in sex determination in this genus (Mair et al., 1991; Baroiller and D'Cotta, 2001; Desprez et al., 2003).

Some studies have found that the identification of the genes involved in the gonadal differentiation of each sex is fundamental to a better understanding of the sex determination mechanism in fish (Siegfried, 2010). These genes have been identified in a few species (Matsuda et al., 2002; Kamiya et al., 2012; Yano et al., 2012) and have been used as chromosomal markers to distinguish pairs of sex chromosomes (Okutsu et al., 2015). In addition, functional genomic studies (transcriptomics) currently applied to fish have identified genes that are complementary to those considered essential for sex determination (Zhang et al., 2011; Yano et al., 2012; Sun et al., 2013; Tao et al., 2013; Lu et al., 2014).

In the present study, crosses between wild females and masculinized genotypic females on average produced progeny with $79.75 \pm 7.20 \%$ females, and that too without the use of exogenous hormones. Because these cohorts were not entirely female, it is possible that autosomal genes or polygenic interactions were involved in the sex determination of $R$. quelen. Overall, the female:male ratio achieved using neomales of $R$. quelen indicates that the farming of this species is feasible because the growth rate of females is $30 \%$ higher than that of males (Baldisserotto and Radünz, 2004), which would lead to a considerable increase in biomass at the end of the production cycle. 


\section{Acknowledgments}

The authors thank the Coordination for the Improvement of Higher Education Personnel (CAPES) for scholarships awarded to the first and second authors. This work was partly supported by the Brazilian National Council for Scientific and Technological Development (CNPq) via the universal project No. 486868/2013-3.

\section{References}

Baldisserotto B, Radünz J. 2004. Criação de Jundiá. , Santa Maria, RS: Ed. UFSM. 232 pp.

Barcellos LJG, Woehl VM, Wassermann GF, Quevedo RM, Ittzés I, Krieger MH. 2001. Plasma levels of cortisol and glucose in response to capture and tank transference in Rhamdia quelen (Quoy \& Gaimard), a South American catfish. Aquacult Res, 32:121-123.

Baroiller JF, Guiguen Y, Fostier A. 1999. Endocrine and environmental aspects of sex differentiation in fish. Cell Mol Life Sci, 55:910-931.

Baroiller JF, D'Cotta H. 2001. Environment and sex determination in farmed fish. Comp Biochem Physiol C Toxicol Pharmacol, 130:399-409.

Cardoso AP, Radünz Neto J, Medeiros TS, Knöpker MA, Lazzari R. 2004. Criação de larvas de Jundiá (Rhamdia quelen) alimentadas com rações granuladas contendo fígados ou hidrolisados. Acta Sci Anim Sci, 26:457-462.

Desprez D, Géraz E, Hoareau MC, Mélard C, Bosc P, Baroiller JF. 2003. Production of a high percentage of male offspring with a natural androgen, 11 $\beta$ hydroxyandrostenedione (11ßOHA4), in Florida Red tilapia. Aquaculture, 216:55-65.

Desprez D, Briand C, Hoareau MC, Mélard C, Bosc P, Baroiller JF. 2006. Study of sex ratio in progeny of a complex Oreochromis hybrid, the Florida Red tilapia. Aquaculture, 251:231-237.

Devlin RH, Nagahama Y. 2002. Sex determination and sex differentiation in fish: an overview of genetic, physiological, and environmental influences. Aquaculture, 208:191-364.

Dias DC, Corrêa CF, Leonardo AF, Tachibana L, Romagosa E, Ranzani-Paiva MJT. 2011. Probiótico na larvicultura de Matrinxã, Brycon amazonicus. Acta Sci Anim Sci, 33:365-368.

Donaldson EM, Devlin RH. 1996. Uses of biotechnology to enhance production. In: Pennell W, Barton BA (Ed.). Developments in Aquaculture and Fisheries Science. Amsterdam: Elsevier Publishers. pp. 969-1020.

Dunham RA. 2004. Aquaculture and Fisheries Biotechnology: Genetic Approaches. Wallingford, UK: CABI. 504 pp.

El-Sayed AFM. 2006. Tilapia Culture. Cambridge, MA: CABI Publishing. 277 pp.

Fenocchio AS, Swarça AC, Cestari MM, Dias AL 2003. Karyotypic characterization and NOR analysis by different banding techniques of Rhamdia quelen (Pisces, Pimelodidae) from the first plateau of the Iguaçu River (Brazil). Folia Biol, 51:3-4.
Feist G, Yeoh C-G, Fitzpatrick MS, Schreck CB. 1995. The production of functional sex-reversed male Rainbow trout with $17 \alpha$-methyltestosterone and $11 \beta$ hydroxyandrostenedione. Aquaculture, 131:145-152.

Fracalossi DM, Zaniboni-Filho E, Meurer S. 2002. No rastro das espécies nativas. Panorama Aquicult, 12:43-49.

George T, Pandian TJ. 1996. Hormonal induction of sex reversal and progeny testing in the Zebra Cichlid Cichlasoma nigrofasciatum. J Exp Zool, 275:374-382.

Ghiraldelli L, Machado C, Fracalossi DM, ZaniboniFilho E. 2007. Desenvolvimento gonadal do jundiá, Rhamdia quelen (Teleostei, Siluriformes), em viveiros de terra, na região sul do Brasil. Acta Sci Biol Sci, 29:349-356.

Gomelsky B. 2003. Chromosome set manipulation and sex control in common carp: a review. Aquat Living Resour, 16:408-415.

Gomes LC, Golombieski JI, Gomes ARC, Baldisserotto B. 2000. Biologia do Jundiá Rhamdia quelen (Teleostei, Pimelodidae). Cienc Rural, 30:179-185. Hunter GA, Donaldson EM, Stoss J, Baker I. 1983. Production of monosex female groups of Chinook salmon (Oncorhynchus tshawytscha) by the fertilization of normal ova with sperm from sex-reversed females. Aquaculture, 33:355-364.

Kamiya T, Kai W, Tasumi S, Oka A, Matsunaga T, Mizuno N, Fujita M, Suetake H, Suzuki S, Hosoya S, Tohari S, Brenner S, Miyadai T, Venkatesh B, Suzuki Y, Kikuchi K. 2012. A trans-species missense SNP in Amhr2 is associated with sex determination in the Tiger Pufferfish, Takifugu rubripes (fugu). PLoS Genet, 8:e1002798. doi.org/10.1371/journal.pgen.1002798.

Kavumpurath S, Pandian TJ. 1994. Masculinization of fighting fish, Betta splendens Regan, using synthetic or natural androgens. Aquacult Res, 25:373-381.

Kirankumar S, Pandian TJ. 2002. Effect on growth and reproduction of hormone immersed and masculinized fighting fish Betta splendens. J Exp Zool, 293:606-616.

Kowalski RK, Sarosiek B, Demianowicz W, Judek J, Goryczko K, Dobosz S, Kuźmiński H, Demska-Zakęś K, Babiak I, Glogowski J. 2011. Quantitative characteristics of Rainbow trout, Oncorhynchus mykiss, neo-males (XX genotype) and super-males (YY genotype) sperm. Int $J$ Biol Biomol Agric Food Biotechnol Eng, 5:315-322.

Longo RS, Nuñer APO. 2010. Temperatures for fertilization and hatching and their influence on determining the sex ratio of the Silver catfish, Rhamdia quelen. Acta Sci Biol Sci, 32:107-111.

Lu J, Luan P, Zhang X, Xue S, Peng L, Mahbooband S, Sun X. 2014. Gonadal transcriptomic analysis of Yellow catfish (Pelteobagrus fulvidraco): identification of sex-related genes and genetic markers. Physiol Genomics, 46:798-807.

Mair GC, Scott AG, Penman DJ, Beardmore JA, Skibinski DOF. 1991. Sex determination in the genus Oreochromis: 1. Sex reversal, gynogenesis and triploidy in O. niloticus (L.). Theor Appl Genet, 82:144-152.

Makino LC, Nakaghi LSO, Paes MCF, Malheiros EB, Dias-Koberstein TCR. 2009. Effectiveness of 
methods of sexual identification in Nile tilapia (Oreochromis niloticus) sexually reverted with hormone in diet with different diameters. Biosci J, 25:112-121.

Matsuda M, Nagahama Y, Shinomiya A, Sato T, Matsuda C, Kobayashi T, Morrey CE, Shibata N, Asakawa S, Shimizu N, Hori H, Hamaguchi S, Sakaizumi M. 2002. DMY is a Y-specific DM-domain gene required for male development in the Medaka fish. Nature, 417:559-563.

Müller-Belecke A, Hörstgen-Schwark G. 1995. Sex determination in tilapia (Oreochromis niloticus) sex ratios in homozygous gynogenetic progeny and their offspring. Aquaculture, 137:57-65.

Nakamura M, Kobayashi T, Chang XT, Nagahama Y. 1998. Gonadal sex differentiation in teleost fish. $J$ Exp Zool, 281:362-372.

Okutsu T, Shikina S, Sakamoto T, Mochizuki M, Yoshizaki G. 2015. Successful production of functional $Y$ eggs derived from spermatogonia transplanted into female recipients and subsequent production of YY supermales in Rainbow trout, Oncorhynchus mykiss. Aquaculture, 446:298-302.

Ospina-Álvarez N, Piferrer F. 2008. Temperaturedependent sex determination in fish revisited prevalence, a single sex ratio response pattern, and possible effects of climate change. PloS One, 3:e2837. doi: 10.1371/journal.pone.0002837.

Pandian TJ, Sheela SG, Kavumpurath S. 1994 Endocrine sex reversal in fishes: masculinization evokes greater stress and mortality. Curr Sci, 66:240-243.

Pandian TJ. 2013. Sex reversal. In: Pandian TJ. Endocrine Sex Differentiation in Fish. Boca Raton, FL: CRC Press. pp. 175-212.

Piferrer F, Donaldson EM. 1989. Gonadal differentiation in Coho salmon, Oncorhynchus kisutch, after a single treatment with androgen or estrogen at different stages during ontogenesis. Aquaculture, 77:251-262.

Piferrer F. 2001. Endocrine sex control strategies for the feminization of teleost fish. Aquaculture, 197:229-281.

Rougeot C, Jacobs B, Kestemont P, Melard C. 2002.
Sex control and sex determinism study in Eurasian perch, Perca fluviatilis, by use of hormonally sexreversed male breeders. Aquaculture, 211:81-89.

Shelton WL, Rodrigues-Guerrero D, Lopes-Macias J. 1981. Factors affecting androgen sex reversal of Tilápia aurea. Aquaculture, 25:59-65.

Siegfried KR. 2010. In search of determinants: gene expression during gonadal sex differentiation. $J$ Fish Biol, 76:1879-1902.

Silveira FS, Silva FM, Casaca JM. 2014. Desempenho Catarinense na Piscicultura de Água Doce. Florianópolis, SC: EPAGRI - CEDAP. 6 pp.

Sulis-Costa R, Jimenez JE, Weingartner M, Nuñer APO. 2013. Efeito da temperatura da água na fase inicial de vida e na proporção sexual do Jundiá. Bol Inst Pesca, 39:379-388.

Sun D, Zhang Y, Wang C, Hua X, Zhang XA, Yan J. 2013. Sox9-related signaling controls Zebrafish juvenile ovary-testis transformation. Cell Death Dis, 4:e930. doi: 10.1038 /cddis.2013.456.

Tao W, Yuan J, Zhou L, Sun L, Sun Y, Yang S, Li M, Zeng S, Huang B, Wang D. 2013. Characterization of gonadal transcriptomes from Nile tilapia (Oreochromis niloticus) reveals differentially expressed genes. PLoS One, 8:e63604. doi: 10.1371/journal.pone.0063604.

Toledo-Filho SA, Forest F, Almeida-Toledo LF. 1996 Cadernos de Ictiogenética III: Biotecnologia Genética Aplicada à Piscicultura. São Paulo, SP: USP. 60 pp.

Woynarovich E, Horváth L. 1983. A Propagação Artificial de Peixes de Águas Tropicais. Brasília, DF: FAO/CODEVASF/CNPq. 225 pp

Yano A, Guyomard R, Nicol B, Jouanno E, Quillet E, Klopp C, Cabau C, Bouchez O, Fostier A, Guiguen Y. 2012. An immune-related gene evolved into the master sex-determining gene in Rainbow trout, Oncorhynchus mykiss. Curr Biol, 22:1423-1428.

Zar JH. 2010. Biostatistical Analysis. 5th ed. Upper Saddle River, NJ:, Prentice Hall. 756 pp.

Zhang J, Chiodini R, Badr A, Zhang G. 2011. The impact of next-generation sequencing on genomics. $J$ Genet Genomics, 38:95-109. 